\title{
Molecular Characterization, Bioinformatic Analysis, and Expression Profile of Lin-28 Gene and Its Protein from Arabian Camel (Camelus dromedarius)
}

\author{
Sultan N. Alharbi ${ }^{1, *,+}\left(\mathbb{D}\right.$, Ibtehal S. Alduhaymi ${ }^{1,+}$, Lama Alqahtani ${ }^{1}$, Musaad A. Altammaami ${ }^{2}$, \\ Fahad M. Alhoshani ${ }^{2}$, Deema K. Alrabiah ${ }^{3}$, Saleh O. Alyemni ${ }^{3}$, Khulud A. Alsulami ${ }^{3}$, \\ Waleed M. Alghamdi ${ }^{2}$ and Mohannad Fallatah ${ }^{1}$ \\ 1 National Center for Stem Cell Technology, King Abdulaziz City for Science and Technology, \\ Riyadh 11442, Saudi Arabia; ialduhaymi@kacst.edu.sa (I.S.A.); lalqahtani@kacst.edu.sa (L.A.); \\ mfallatah@kacst.edu.sa (M.F.) \\ 2 National Center for Biotechnology, King Abdulaziz City for Science and Technology, \\ Riyadh 11461, Saudi Arabia; mtammami@kacst.edu.sa (M.A.A.); fhoshani@kacst.edu.sa (F.M.A.); \\ wghamdi@kacst.edu.sa (W.M.A.) \\ 3 National Center for Pharmaceutical Technology, King Abdulaziz City for Science and Technology, \\ Riyadh 11461, Saudi Arabia; dalrabiah@kacst.edu.sa (D.K.A.); saleh.o.alyemni@hotmail.com (S.O.A.); \\ kaalsulami@kacst.edu.sa (K.A.A.) \\ * Correspondence: snharbi@kacst.edu.sa; Tel.: +966-11-4883-555 (ext. 1836) \\ + These authors contributed equally to this work.
}

Received: 9 March 2019; Accepted: 5 May 2019; Published: 9 May 2019

\begin{abstract}
Lin-28 is an RNA-binding protein that is known for its role in promoting the pluripotency of stem cells. In the present study, Arabian camel Lin-28 (cLin-28) cDNA was identified and analyzed. Full length cLin-28 mRNA was obtained using the reverse transcription polymerase chain reaction (RT-PCR). It was shown to be $715 \mathrm{bp}$ in length, and the open reading frame (ORF) encoded 205 amino acids. The molecular weight and theoretical isoelectric point (pI) of the cLin-28 protein were predicted to be $22.389 \mathrm{kDa}$ and 8.50, respectively. Results from the bioinformatics analysis revealed that cLin-28 has two main domains: an N-terminal cold-shock domain (CSD) and a C-terminal pair of retroviral-type Cysteine3Histidine (CCHC) zinc fingers. Sequence similarity and phylogenetic analysis showed that the cLin-28 protein is grouped together Camelus bactrianus and Bos taurus. Quantitative real-time PCR (qPCR) analysis showed that cLin-28 mRNA is highly expressed in the lung, heart, liver, and esophageal tissues. Peptide mass fingerprint-mass spectrometry (PMF-MS) analysis of the purified cLin-28 protein confirmed the identity of this protein. Comparing the modeled $3 \mathrm{D}$ structure of cLin-28 protein with the available protein 3D structure of the human Lin-28 protein confirmed the presence of CSD and retroviral-type CCHC zinc fingers, and high similarities were noted between the two structures by using super secondary structure prediction.
\end{abstract}

Keywords: Arabian Camel; Lin-28; PMF-MS; 3D structure; cold-shock domain (CSD); bioinformatics analysis; phylogenetic analysis

\section{Introduction}

The domesticated one-humped camel (Camelus dromedarius) belongs to the camelidae family. It plays a major role in the culture and way of life in the Middle East, not only because of its economic benefits in terms of milk and meat production, but also as an ideal model animal for medical study [1]. Although there has been an increasing number of studies on camels in recent years [2,3], structural and biomolecular research of Arabian camel proteins has been limited. The Arabian camel genome is 
composed of 74 chromosomes. The DNA sequence of camels reveals wide differences with other species, including human and mice; nevertheless, functional similarities remain. Therefore, studies of Arabian camel proteins offer a potentially viable target for human clinical applications.

Lin-28 is a conserved RNA-binding protein that is highly expressed in embryonic stem cells $[4,5]$. It plays several main cellular functions, including differentiation, development, and glucose metabolism, but its two main functions are the inhibition of let-7 microRNA and the regulation of target mRNA translation [6]. The Lin-28 protein consists of two main domains, an N-terminal cold-shock domain (CSD) and a C-terminal pair of retroviral-type CCHC zinc fingers [4], which act as both negative regulators of let-7 miRNA biogenesis and are post-transcriptional regulators of mRNA translation [7]. These two domains are highly conserved among mammals. Lin-28 can be localized in both the nucleus and cytosol of cells and interacts with the precursor of let-7 microRNA in order to prevent its maturation [8,9]. CSD, with its $\beta$-barrel structure, can bind single-stranded nucleic acids, therefore causing translational repression and activation of mRNA in undifferentiated and differentiated cells [10]. Lin-28 and the other heterochronic genes are unique among the developmental regulators of mammalian species, as they globally coordinate the relative timing of various developmental circumstances. It is unknown whether developmental timing mechanisms and several parts of developmental patterning are commonly conserved, or whether they show great differences among species [11].

In spite of the fact that the Lin-28 protein has been highly characterized in humans, C. elegans and drosophila [12,13], there are no reports of the Lin-28 protein from the Arabian camel (cLin-28). The main aim of the present study was to obtain the full-coding sequence of cLin-28 mRNA and to identify its amino acid sequence. Furthermore, The tissue-specific expression level of the cLin-28 protein was examined across 11 different Arabian camel tissues. We believe that this genetic and structural information will be a helpful source for the annotation of the Arabian camel genome. We also assume that the study of biochemical and biophysical properties of cLin-28 gene is likely to provide molecular insights into Arabian camel genome.

\section{Results}

\subsection{Tissue-Specific Expression Profile of cLin-28 mRNA}

The expression of cLin-28 mRNA was examined in 11 different tissues of Arabian camel (Figure 1). Specific primers (Table 1) were designed to amplify about $636 \mathrm{bp}$ for cLin-28 and $190 \mathrm{bp}$ for GAPDH genes (as an endogenous control). In addition, the level of expression of cLin-28 mRNA in the 11 different tissues was examined using qPCR. The qPCR specific primers were also designed to amplify 101 and $80 \mathrm{bp}$ for cLin- 28 and $\beta$-actin mRNAs, respectively. The maximum expression of cLin- 28 mRNA was noted in the Arabian camel lung, heart, liver, and esophagus, followed by nearly equal expression in the kidney, and testis, whereas the lowest expression was noted in the spleen, small intestine, brain, and muscle tissues (Figure 2).

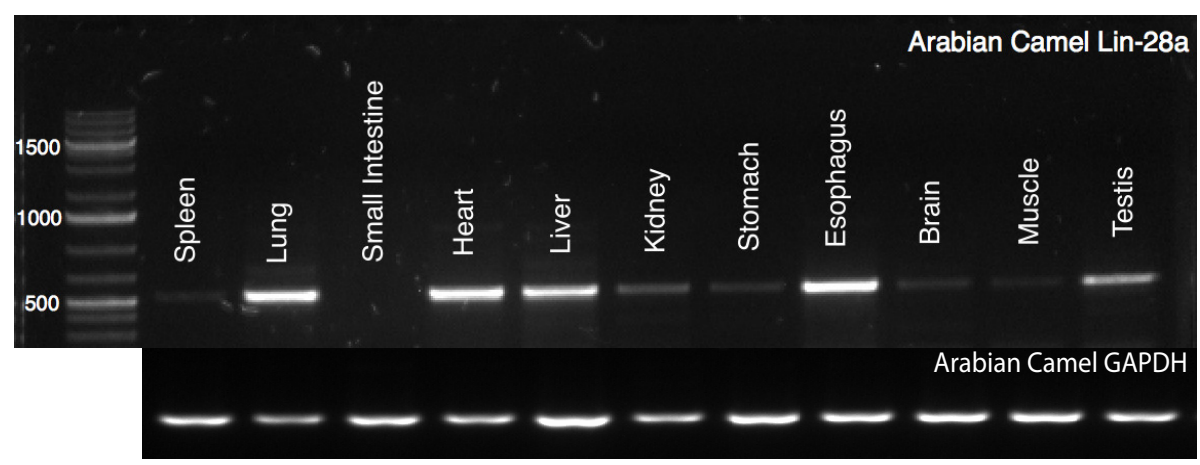

Figure 1. Agarose gel (1.2\%) electrophoresis of PCR products for cLin-28 mRNA, 1500 bp DNA molecular weight marker was used. 


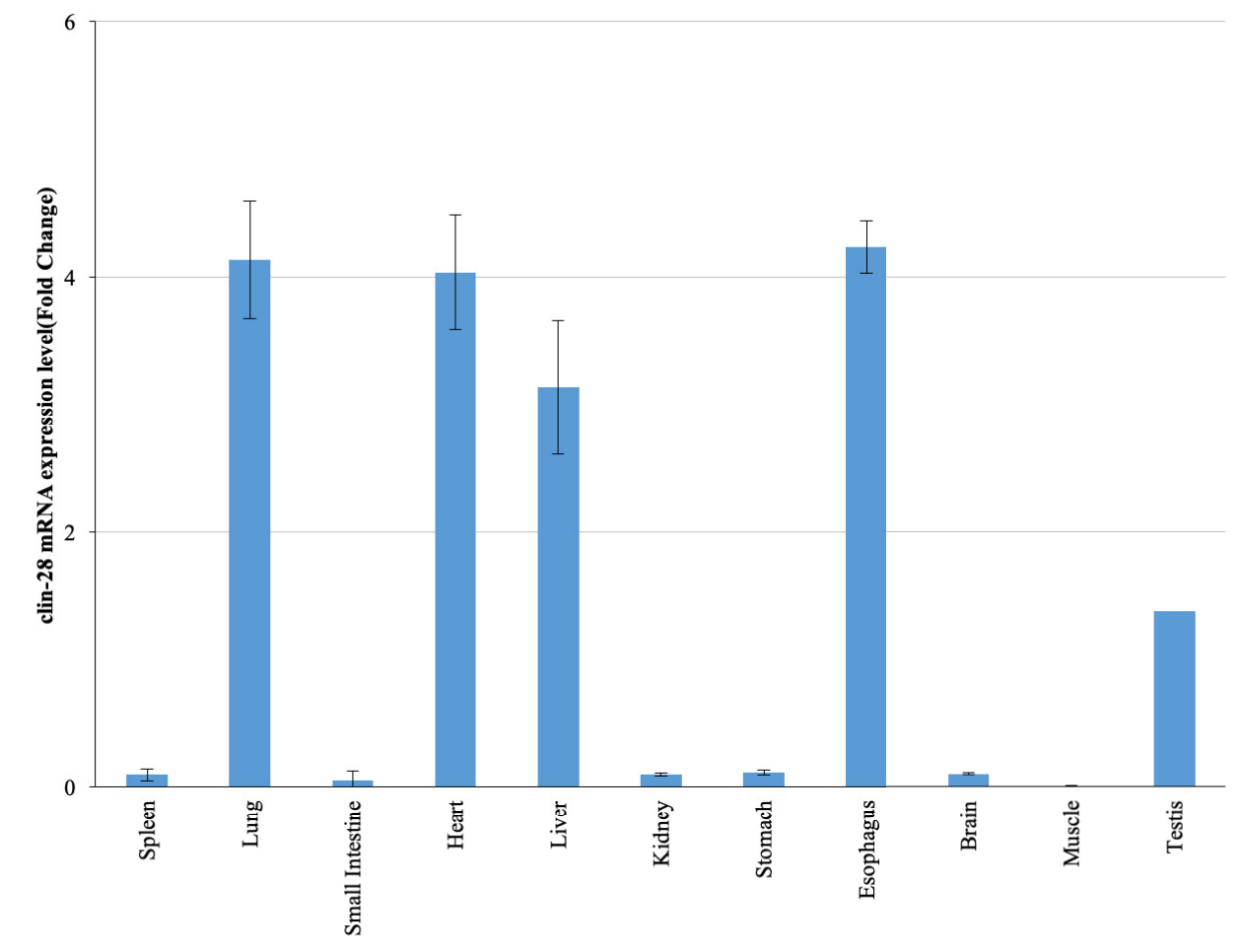

Figure 2. cLin-28 mRNA expression levels in different tissues. The results are expressed relative to an endogenous control, $\beta$-actin.

Table 1. List of primers used for the amplification and sequencing studies.

\begin{tabular}{|c|c|c|c|}
\hline Usage & Primer Name & Primer Sequence $5^{\prime} \rightarrow 3^{\prime}$ & Length (bp) \\
\hline \multirow[t]{4}{*}{ ORF-PCR } & cLin-28-F & ACTACCATGGGCTCTGTGTC & 636 \\
\hline & cLin-28-R & ACCCACTGTGGCTCAATTCT & \\
\hline & GAPDH-F & CTGGGAAGATGTGGCGTGAT & 190 \\
\hline & GAPDH-R & AAGGCCATGCCAGTTAGCTT & \\
\hline \multirow[t]{4}{*}{ qRT-PCR } & cLin-28-qF & AAAGCCAGCCTACTTTCGGG & 101 \\
\hline & cLin-28-qR & CAAAAGGATAGCCCCCACCC & \\
\hline & $\beta$-Actin-F & CCCATTGAGCATGGCATCGT & 80 \\
\hline & $\beta$-Actin-R & GTAGATGGGCACAGTGTGAG & \\
\hline
\end{tabular}

\subsection{Characterization of the Full Coding cLin-28 Gene}

The sequence suggested that the fragment has a length of $715 \mathrm{bp}$. This sequence characterized the first cLin-28 mRNA from the Arabian camel. Based on sequence homology, the full coding regions were compared with the corresponding regions from other counterparts. The sequence represents the first full coding region of the lin-28 gene from the Arabian camel and was submitted to the NCBI GenBank (accession number MK562530). The predicted amino acid sequence of cLin-28 mRNA was found to consist of an open reading frame (ORF) of 205 amino acid residues (Figure 3). The amino acid sequence was submitted to the gene bank (accession number XP_010992036). The BLAST analysis for the coding region of cLin-28 revealed that it shared high similarity $(98.1-79 \%)$ with Lin-28 from other species (Figure 4). 


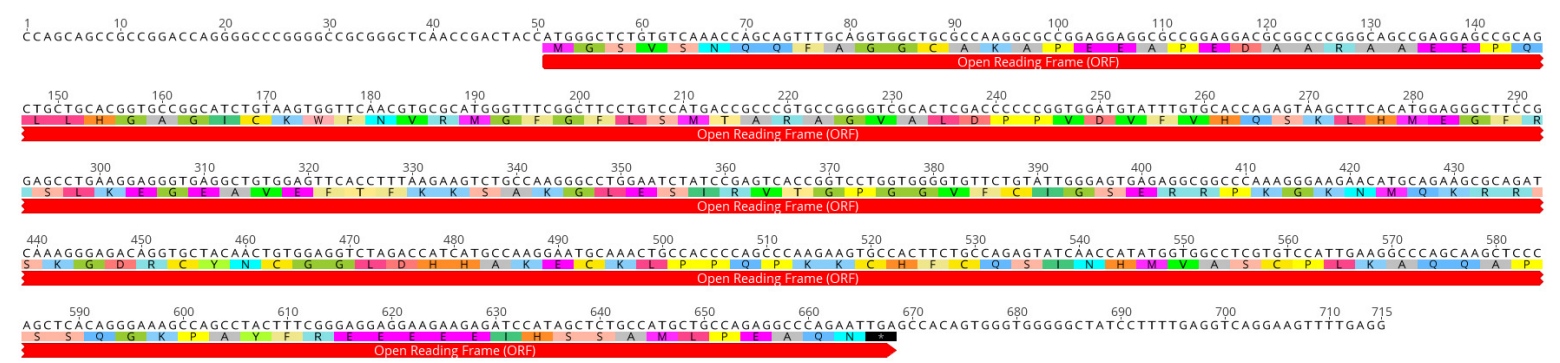

Figure 3. The nucleotide sequence and the deduced amino acids of Arabian camel Lin-28. The sequence was submitted to NCBI GenBank (accession number MK562530).

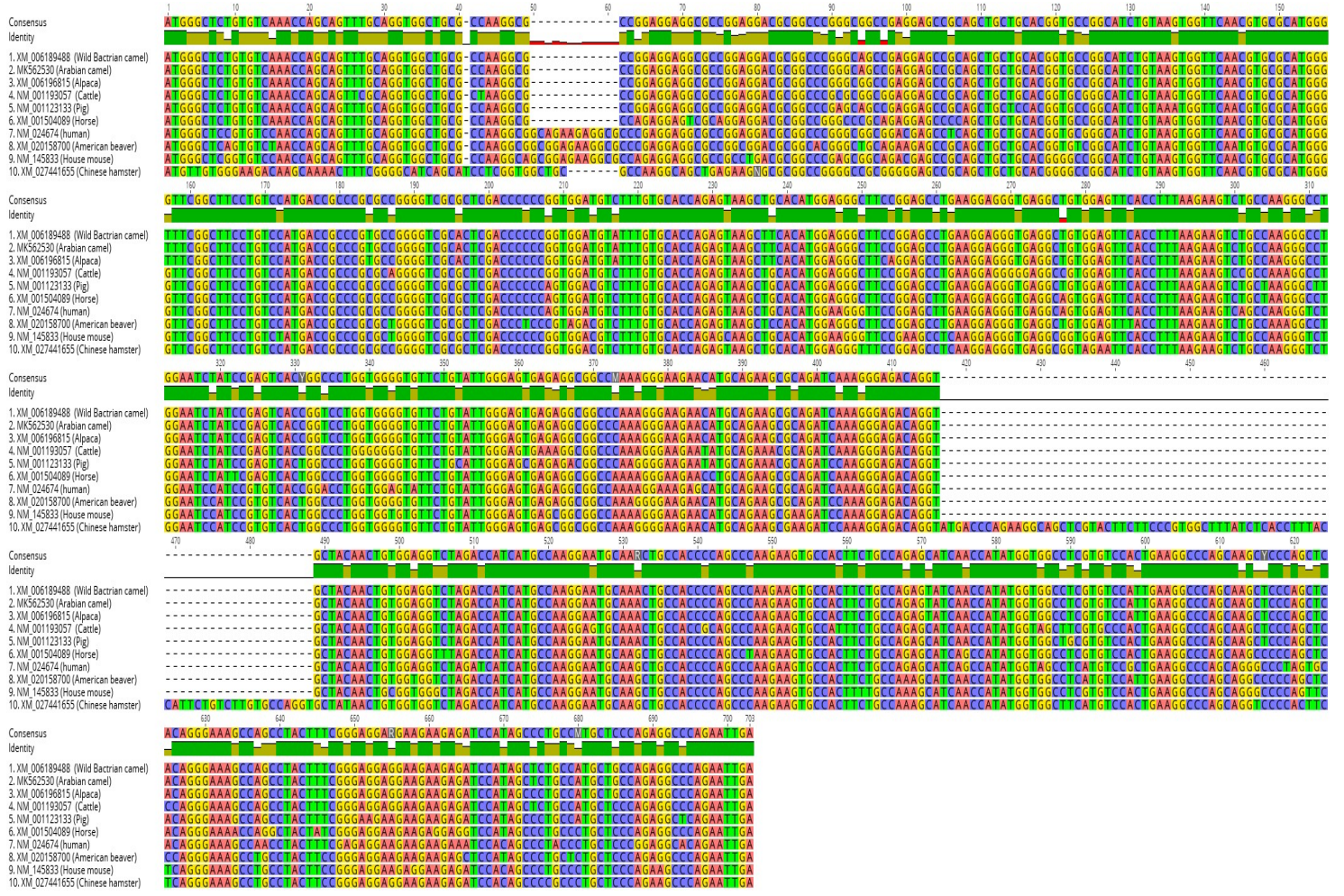

Figure 4. Multiple alignment of the nucleotide sequence of cLin-28 mRNA with nine other mammalian species. Identical nucleotides are marked in green.

\subsection{Identification of cLin-28 Protein by Using Mass Spectrometry}

The molecular analysis of the 205 amino acid sequence of the cLin-28 protein using the Geneious software [14] predicted that this protein has a molecular weight (Mwt) of $22.389 \mathrm{kDa}$ and an isoelectric point (pI) of 8.50 (Figure 5a). Accordingly, for peptide mass fingerprint mass spectrometry (PMF-MS), the targeted protein spot obtained from the separation of proteins with two-dimensional polyarylamide gel electrophoresis (2-DE) was manually excised (Figure 5b) and subjected to MS analysis for the identification of the cLin-28 protein. Of the total trypsin-digested peptide mass of cLin-28 protein, 11 peptides, which covered $48 \%$ (Figure $5 \mathrm{c}$ ) of the entire protein sequence, were hit in the NCBIprot database (containing 4540232 sequences) by using the Mascot peptide fingerprint search engine with cLin-28 protein (accession no. XP_010992036) with a score of 120 and $p<0.05$.

The mass spectrum revealed several protonated ions $[\mathrm{M}+\mathrm{H}]+$ in the peptide fragments (Figure $5 \mathrm{~d}$ ). The ions at 1353.6800, 1155.5100, 1537.5300, 2240.1300, 721.4700, 889.4300, 1157.6300, 1378.8600, 705.380, 807.5000 , and 1001.2400 were the 11 trypsin digested peptides corresponding to amino acids $2-15,16-26$, $27-41,27-46,42-46,75-81,85-94,105-118,122-127,150-156$, and 174-183, respectively. As shown in 
Table 2, the peptide mass profiles were retrieved from NCBIprot database search engine, and the amino acid sequence of each digested peptide was recognized from the sequence of cLin- 28 protein from the extracted spot of this protein on the 2-DE gel. The PMF-MS results also aligned with those from other species; the second best matching protein had a score of 120 for alpaca (accession no. XP_006196877.1) Lin-28 protein. The third and fourth best matching proteins also scored with 120 for pig (accession no. ADK26463.1) and cattle (accession no. NP_001179986.1) Lin-28 proteins.

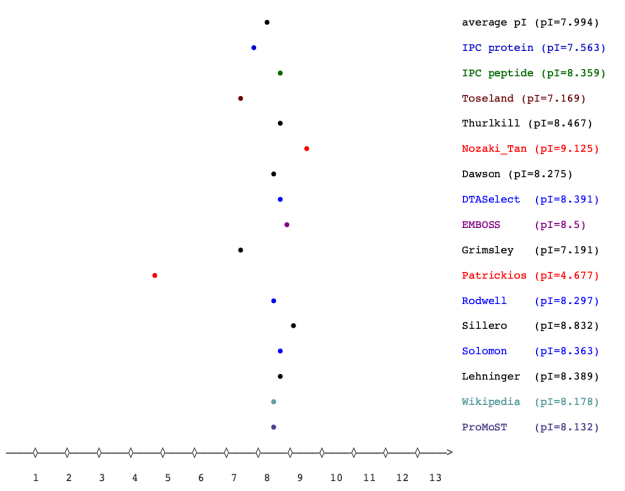

(a)

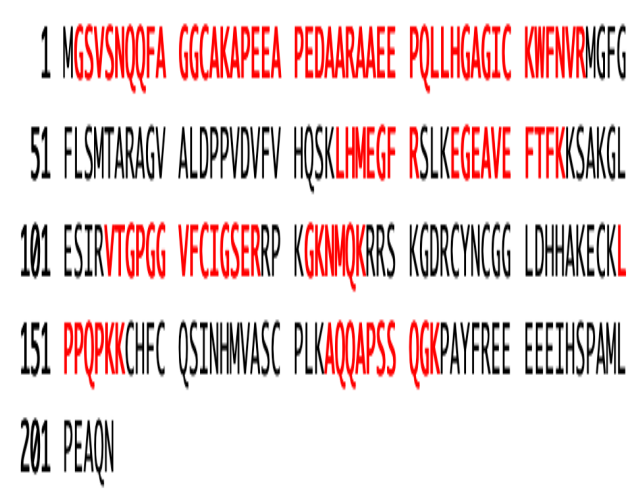

(c)

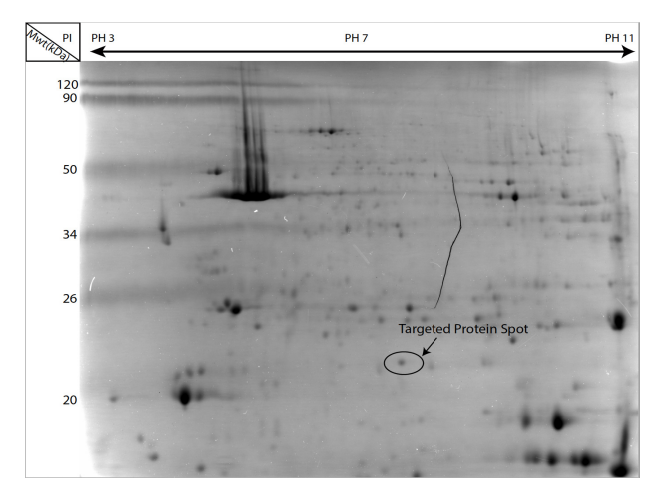

(b)

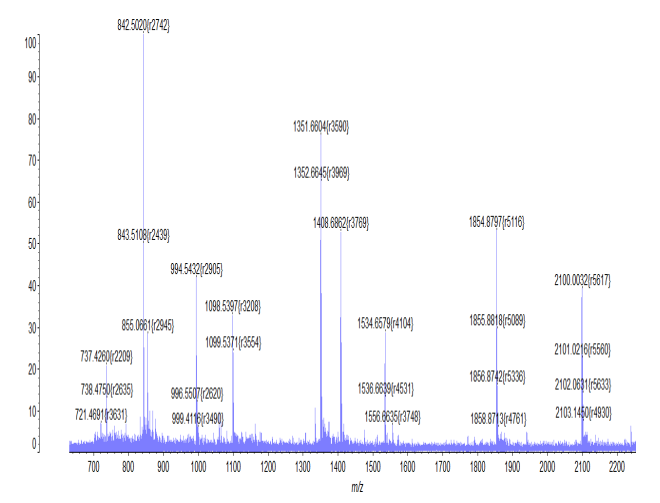

(d)

Figure 5. Liquid chromatography-mass spectrometry (LC-MS). (a) Isoelectric point (pI) of cLin-28 protein according to different scale calculations. (b) 2D-gel SDS page. (c) MLDI-TOF MS-derived peptides (red) matched to the sequence of cLin-28 protein. (d) Observed peak list of peptides from the cLin-28 protein.

Table 2. Observed and calculated ions of peptide masses of cLin-28 protein.

\begin{tabular}{cccc}
\hline Amino Acid Positions & \multicolumn{2}{c}{$[\mathbf{M}+\mathbf{H}]+$} \\
\hline Start-End & $\mathrm{B}$ & Calculated $\mathbf{( m / z )}$ & Peptide Sequence \\
\hline $2-15$ & 1353.6800 & 1353.4608 & MGSVSNQQFAGGCAKA \\
$16-26$ & 1155.5100 & 1155.1723 & KAPEEAPEDAARA \\
$27-41$ & 1537.5300 & 1536.7512 & RAAEEPQLLHGAGICKW \\
$27-46$ & 2240.1300 & 2239.5544 & RAAEEPQLLHGAGICKWFNVRM \\
$42-46$ & 721.4700 & 720.8185 & KWFNVRM \\
$75-81$ & 889.4300 & 889.0332 & KLHMEGFRS \\
$85-94$ & 1157.6300 & 1156.2416 & KEGEAVEFTFKK \\
$105-118$ & 1378.8600 & 1378.5532 & RVTGPGGVFCIGSERR \\
$122-127$ & 705.3800 & 704.8391 & KGKNMQKR \\
$150-156$ & 807.5000 & 806.9923 & KLPPQPKKC \\
$174-183$ & 1001.2400 & 1001.0520 & KAQQAPSSQGKP \\
\hline
\end{tabular}




\subsection{Amino Acid Composition and Homology of cLin-28 Protein}

The biological activity of the cLin-28 protein depends on the nature of its amino acid composition. The cLin-28 protein contains 70 charged (40.88\%), 59 hydrophobic $(27.24 \%), 23$ acidic $(12.95 \%)$, 28 basic $(17.41 \%)$, and 46 polar amino acids (22.15\%). The complete amino acid analysis and chemical composition of the predicted protein are illustrated in Table 3. The instability index [15] of the cLin-28 protein was also measured to be 58.89 , which classified the protein as unstable $(>40)$. The aliphatic index and the grand average of hydropathicity (GRAVY) of cLin-28 were 54.83 and -0.579 , respectively. Different methods were utilized to evaluate the hydrophilicity and hydrophobicity of the cLin-28 protein along its amino acid sequence (Figure 6). The Kyte and Doolittle method [16] provides a graphic visualization to track the hydrophobic and hydrophilic regions of cLin-28 protein relative to a universal midpoint line (Figure 6a). This scale identified the surface-exposed regions of the protein at its C-terminal. The four major regions above the midpoint line indicate internal regions, whereas, the seven major regions of the profile that lie below the midpoint line are external regions of the cLin-28 protein. In order to predict the major antigenic determinants of the cLin-28 protein, Hopp and Woods' method [17] was used. The plot-generated prediction profile for the cLin-28 protein is shown in Figure 6b. The largest peaks correspond to amino acids 120-140, and amino acids 180-190 represent the most hydrophilic segments of the protein and are associated with the antigenic site. The deepest valley (amino acids 40-60) is associated with longest helical secondary structure element (Figure 7).

Table 3. Predicted chemical composition of the cLin-28 protein.

\begin{tabular}{cccc}
\hline Amino Acid & Number Count & \% By Weight & \% By Frequency \\
\hline Ala (A) & 21 & 6.67 & 10.24 \\
Cys (C) & 9 & 4.15 & 4.39 \\
Asp (D) & 5 & 2.57 & 2.44 \\
Glu (E) & 18 & 10.38 & 8.78 \\
Phe (F) & 11 & 7.23 & 5.37 \\
Gly (G) & 20 & 5.10 & 9.76 \\
His (H) & 8 & 4.90 & 3.90 \\
Ile (I) & 5 & 2.56 & 5.37 \\
lys (K) & 17 & 9.73 & 8.29 \\
Leu (L) & 11 & 5.56 & 5.37 \\
Met (M) & 7 & 4.10 & 3.41 \\
Asn (N) & 6 & 3.06 & 2.93 \\
Pro (P) & 14 & 6.07 & 6.83 \\
Gln (Q) & 11 & 6.30 & 5.37 \\
Arg (R) & 11 & 7.67 & 5.37 \\
Ser (S) & 15 & 5.83 & 7.32 \\
Thr (T) & 3 & 1.35 & 1.46 \\
Val (V) & 10 & 4.43 & 4.88 \\
Trp (W) & 1 & 0.88 & 0.49 \\
Tyr (Y) & 2 & 1.46 & 0.98 \\
\hline
\end{tabular}

The flexibility of cLin-28 protein is important for its actions as a transcriptional factor. The Karplus and Schulz approch [18] was utilized to predict the structural flexibility of cLin-28 protein (Figure 6c). The flexibility analysis revealed that the N-terminal of the cLin-28 protein is more flexible than its C-terminal regions. Consequently, those flexible regions can be considered epitopic regions for this protein as they are constructed from surface amino acids rather than internal amino acids. Furthermore, B cell epitopes were predicted by using the Kolaskar and Tongaonkar antigenicity method [19] (Figure 6d). The average antigenic tendency value for this protein was 1.023 with a minimum value of 0.888 and a maximum value of 1.182. The results also showed that this protein has five possible antigenic peptides, with different lengths ranging from six to 33 amino acids. Amongst them, the two most preferred B cell epitope characteristics were observed for amino acids 58 to 74 and 143 to 
175 (Table 4). In order to recognize the amino acids that are on the surface of the cLin-28 protein, Emini surface accessibility prediction [20] was utilized (Figure 6e). Amino acids located on a specific area in the cLin- 28 protein can bind to the $\mathrm{B}$ cell receptor, and the area must be on the surface and immunogenetic. The maximum surface probability value for the cLin28 protein was found to be 5.957 from amino acid positions 115 to 135. In addition, Chou and Fasman $\beta$-turn prediction [21] predicts the epitope-based on the turn structure degree. It suggested that the epitope must always be found in the $\beta$-shaped turn structure. The results suggested that this protein is rich in $\beta$-turns in the region between amino acids 105 to 145 , which is the region where $\beta$-strands are directed in anti-parallel to form $\beta$-sheets (Figure 6f).

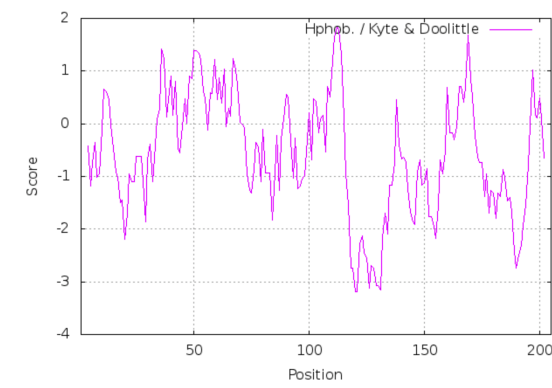

(a)

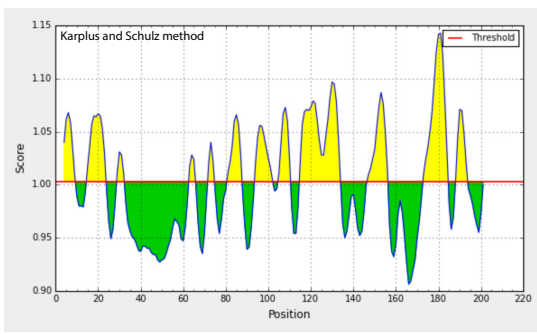

(c)

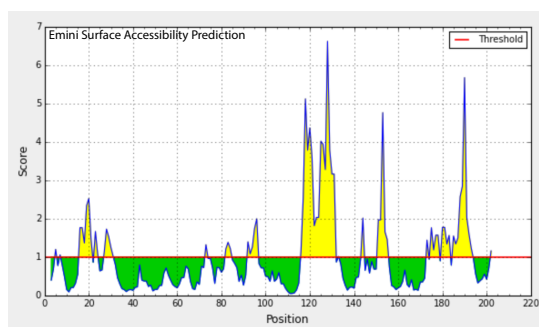

(e)

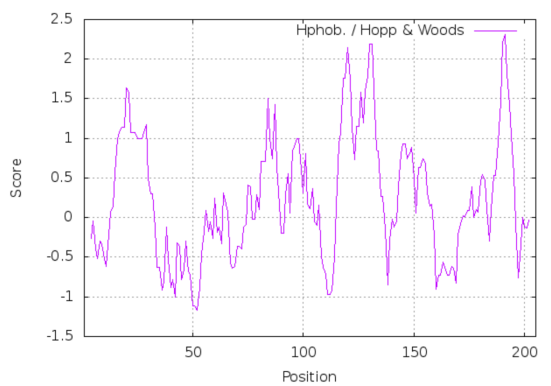

(b)

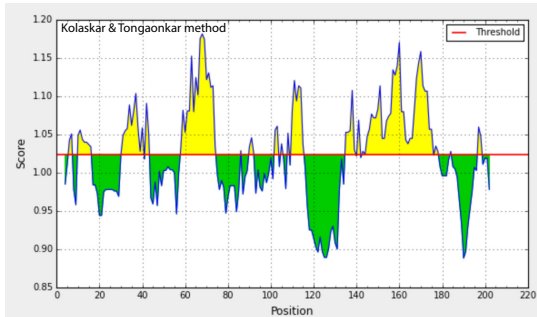

(d)

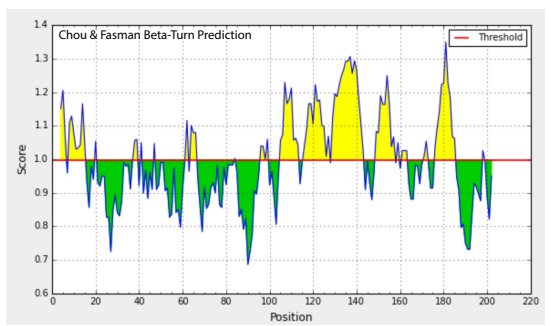

(f)

Figure 6. Hydrophatic profiles of the cLin-28 protein. Plots have amino acid sequence positions on the $\mathrm{x}$-axis, and the degree of hydrophobicity and hydrophilicity on the y-axis. (a) Kyte-Doolittle method: the points above the midpoint line denote the hydrophopic regions and those below the midpoint line indicate hydrophilic regions of the cLin-28 protein. (b) Hydrophilicity plot for cLin-28 protein using the Hopp and Wood method. (c) Karplus and Schulz flexibility prediction of the cLin-28 protein. The x-axis and y-axis represent the position and score, respectively. The threshold is 1.0. The flexible regions of the protein above the threshold value are shown in yellow. (d) Kolashkar and Tongaonkar antigenicity prediction of the most antigenic regions of the cLin-28 protein. The threshold value is 1.0. The regions above the threshold are antigenic and are shown in yellow. (e) Emini surface accessibility prediction of the cLin-28 protein. The threshold value is 1.000 . The regions above the threshold are antigenic and are shown in yellow. (f) Chou and Fasman $\beta$-turns prediction of clin-28 protein. The threshold is 1.00. The regions with $\beta$-turns in the protein are shown in yellow. 
Table 4. Predicted antigenic peptides using the Kolaskar and Tongaonkar antigenicity method.

\begin{tabular}{ccccc}
\hline No. & Start & End & Peptide & Length \\
\hline 1 & 10 & 16 & AGGCAKA & 7 \\
2 & 31 & 40 & PQLLHGAGIC & 10 \\
3 & 58 & 74 & AGVALDPPVDVFVHQSK & 17 \\
4 & 110 & 115 & GVFCIG & 6 \\
5 & 143 & 175 & HHAKECKLPPQPKKCHFCQSINHMVASCPLKAQ & 33 \\
\hline
\end{tabular}

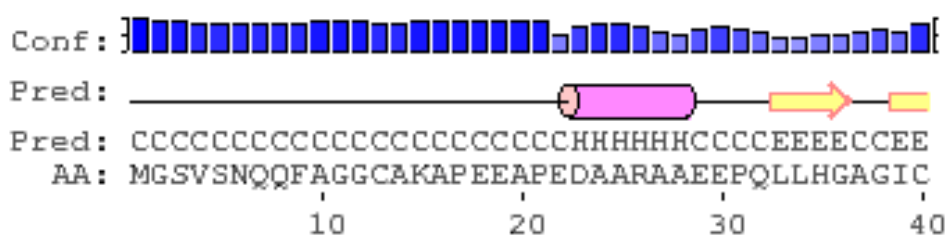

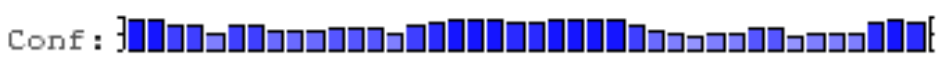

Pred : $\Longrightarrow \longrightarrow \longrightarrow$

Pred: EEEECCCCEEEEECCCCCCCCCCCCCCCCCCCCEEECCCC

AA : KWFNVRMGF GE LSMTARAGVALDPPVDVFVHQSKLHMEGE '́ 10 'ं0

Conf : \} З :

Pred:

Pred: CCCCCCCEEEEEEEECCCCCEEEEEECCCCCCCCCCCCCC

AA: RSLKEGEZVEF TFKKSAKGLES IRVTGPGGVF CIGSERRP,

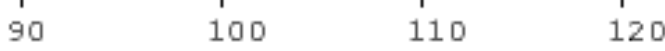

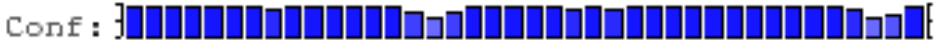

Pred:

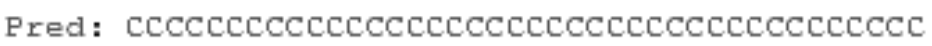

AA : KGKNWQKRRSKGDRCYNCGGLDHHAKE CKLPPQPKKCHFC

$\begin{array}{llll}130 & 140 & 150 & 160\end{array}$

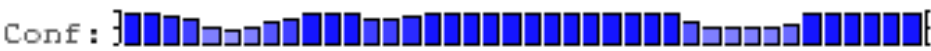

Pred:

Pred: CCCCCCCCCCCCCCCCCCCCCCCCCCCCCHHHHCCCCCCC

AA : QS INHMVASCPLKZQQAPSSQGKPAYF REEEEEIHSSAML

$\begin{array}{llll}170 & 180 & 190 & 200\end{array}$

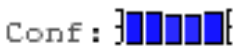

Pred:

Pred: CCCCC

$A A$ : PEZQN

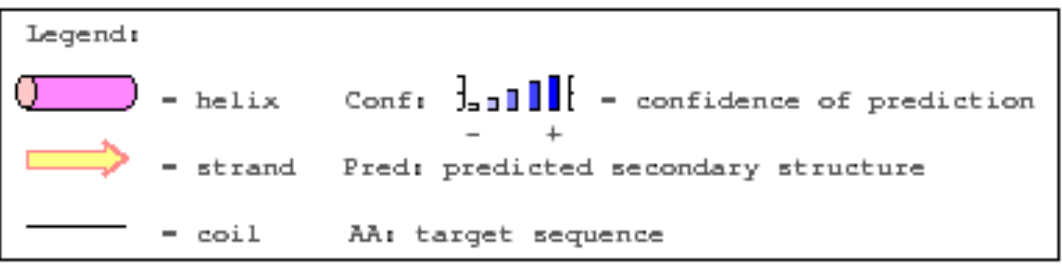

Figure 7. The secondary structure of the cLin-28 protein. 


\subsection{Multiple Sequence Alignment}

The amino acid sequence of the cLin-28 molecule was aligned with those of nine other mammalian species by ClustalW [22]. The two main domains-an N-terminal cold-shock domain (CSD) and a C-terminal pair of retroviral-type CCHC zinc fingers-were highly conserved for all aligned proteins. This protein binds to a pri- and pre-let-7 microRNA and represses their processing by Drosha and Dicer. Many biochemical and structural observations have revealed that the specificity of this interaction is mainly carried by the zinc finger domain with a conserved GGAGA motif. The cLin-28 protein shares an overall sequence identity of $80 \%$ and contains low-complexity regions at the $\mathrm{N}$-terminus (Figure 8 ). The BlastP analysis [23] revealed that the cLin-28 protein shares high similarity with Lin-28 proteins from other mammalian species. The highest similarity was found with alpaca $(98.6 \%)$, cattle $(98.1 \%)$, pig $(98.1 \%)$, Chinese hamster (96.2\%), American beaver (96.2\%), house mouse (95.7\%), and horse (94.6\%) proteins (Table 5 and Figure 8). In addition, multiple alignment analysis revealed that the RNA-binding domains of the Lin28 protein are highly conserved. This high resemblance suggests a close evolutionary relationship. The phylogenetic tree grouped this cLin-28 protein with wild bactrian camel and cattle (Figure 9) using the neighbor-joining method [24]. In order to predict the binding regions of the cLin-28 protein, the ANCHOR web-server [25] was used (Figure 10a). As shown in the figure, the N-terminal aspect of the cLin-28 protein is predicted to be the ordered region, whereas its $\mathrm{C}$-terminal part is predicted to be the disordered region. The cLin-28 protein contains less disordered regions than the globular one (Figure 10b).

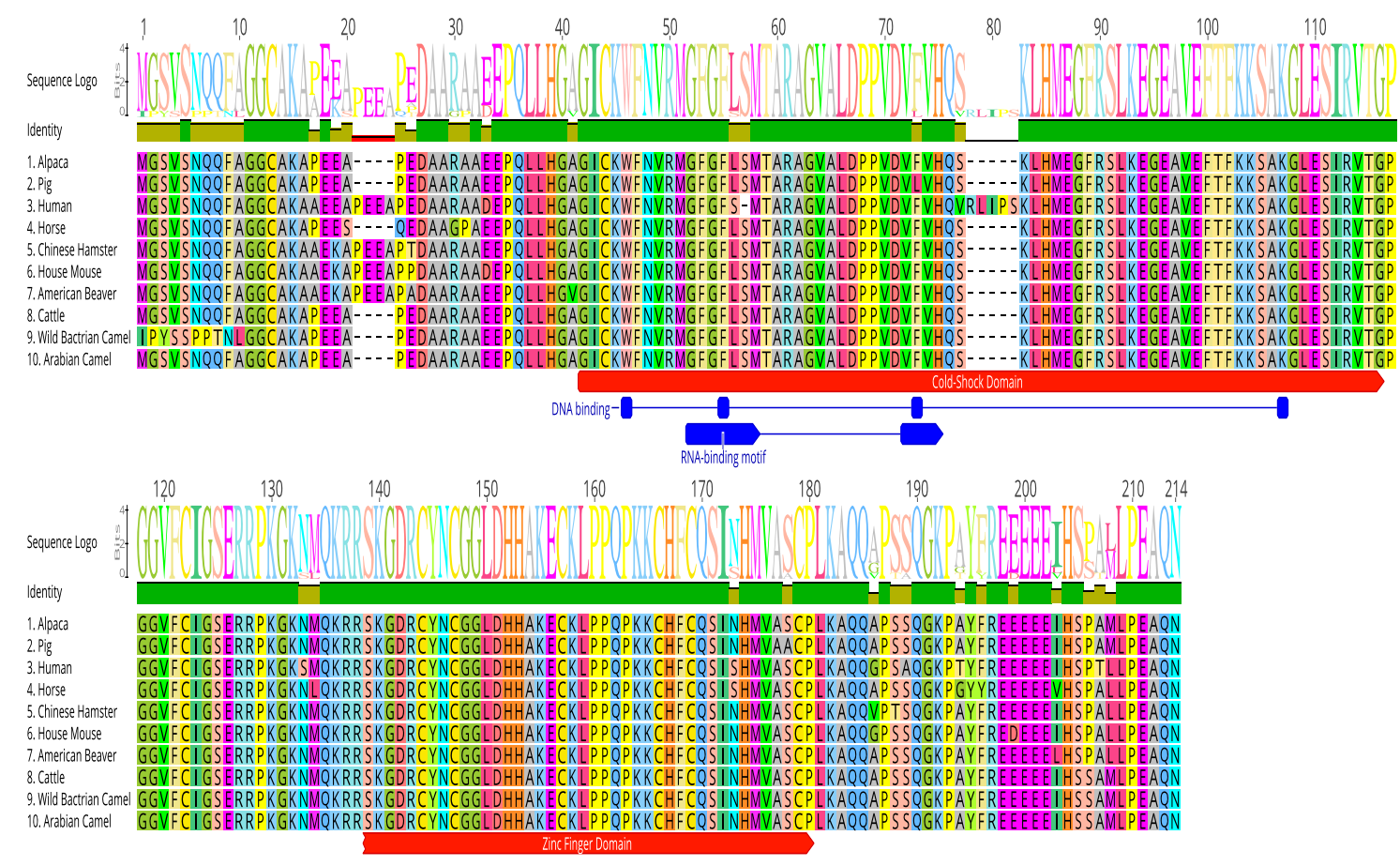

Figure 8. Multiple alignment of the amino acid sequence of cLin-28 protein with nine other mammalian species. Identical amino acids are marked in green, and typical cold shock and zinc finger domains are shown in red. RNA/DNA-binding domains are revealed in blue. 


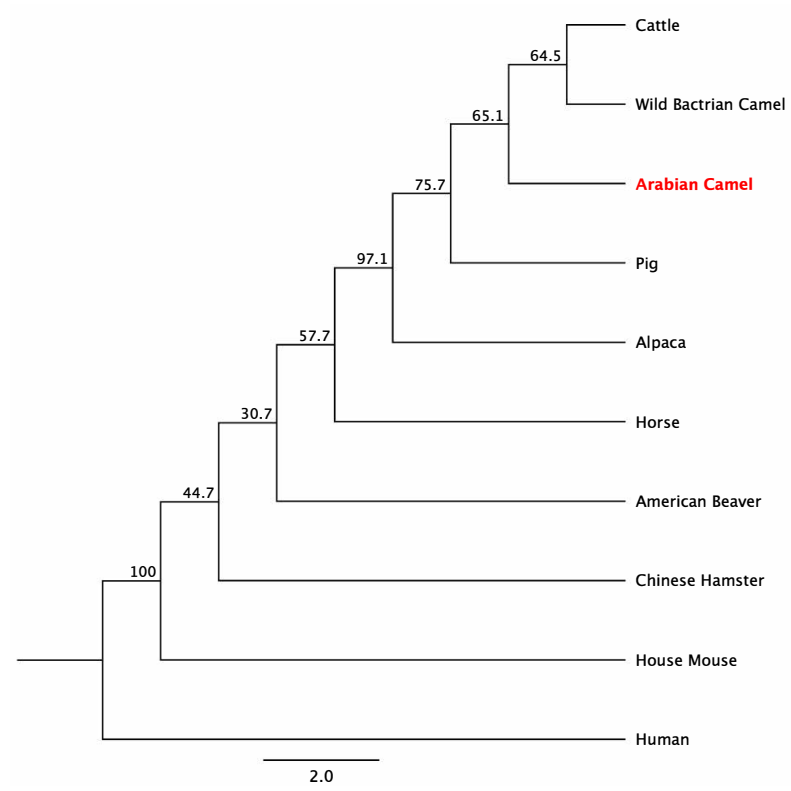

Figure 9. The phylogenetic tree shows the relationship of the cLin-28 protein with protein sequences from other species. The maximum likelihood tree is based on complete coding sequences. The values at nodes are bootstrapping $30 \%$ obtained from 1000 -fold data re-sampling.

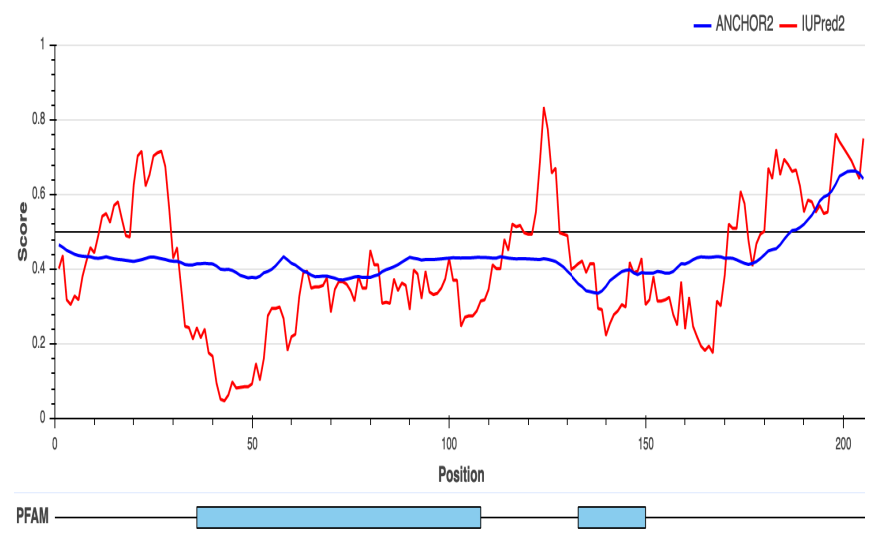

(a)

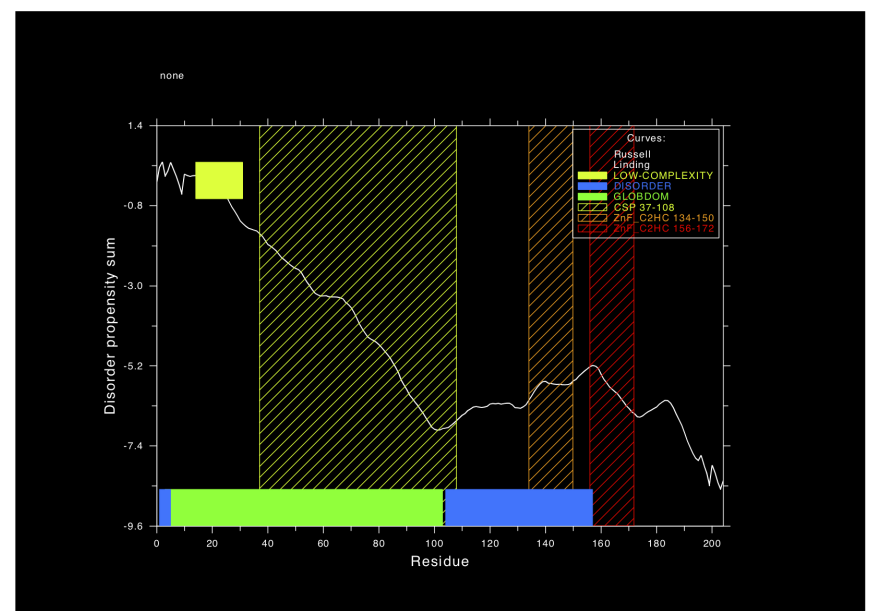

(b)

Figure 10. (a) Prediction of the binding regions of the cLin-28 protein. (b) The globular and disordered regions in the cLin-28 protein. 
Table 5. Homology of cLin-28 amino acids with those from other species.

\begin{tabular}{ccccc}
\hline Species & Common Name & Protein(Accession no.) & Protein Length (bp) & Identity (\%) \\
\hline Homo sapiens & Human & EAX07815.1 & 360 & 80 \\
Mus musculus & House Mouse & AAH68304.1 & 209 & 95.7 \\
Sus scrofa & Pig & ADK26463.1 & 205 & 98.1 \\
Camelus bactrianus & Wild Bactrian Camel & EPY77519.1 & 232 & 88.6 \\
Camelus dromedarius & Arabian Camel & XP_010992036 & 205 & 100 \\
Vicugna pacos & Alpaca & XP_006196877.1 & 205 & 98.6 \\
Bos taurus & Cattle & NP_001179986.1 & 205 & 98.1 \\
Equus przewalskii & Horse & XP_001504139.1 & 205 & 94.6 \\
Cricetulus griseus & Chinese hamster & ERE84162.1 & 209 & 96.2 \\
Castor canadensis & American beaver & XP_020014289.1 & 209 & 96.2 \\
\hline
\end{tabular}

\subsection{Secondary and 3D Structures of cLin-28 Protein}

The secondary structure of the cLin-28 protein is a regular repeating folding pattern within this protein which is stabilized by hydrogen bonds between the amino and keto groups of the peptide bonds. The primary structure of the cLin- 28 protein was utilized to predict its secondary structure, which revealed the first level of protein folding. The predicted structure demonstrated that the cLin- 28 protein is composed of two $\alpha$-helices and six $\beta$-strands (Figure 7), in which the six $\beta$-stranded structure forms a highly conserved CSD of about 80 amino acids (from 40 to 120 amino acids). A prediction of the secondary structure analysis of cLin-28 protein was carried out using PSIPRED server [26].

The activity and biochemical functions of the cLin- 28 protein were determined by its three-dimensional (3D) shape. The 3D structure of the cLin-28 protein was predicted using homology structure modeling on the Phyre2 server [27]. Fold recognition with Phyre2 software retrieved the crystal structure of the human Lin-28 cold shock domain as the top hit with $99 \%$ confidence and $80 \%$ identity (PDB ID 4A4I). The predicted 3D structure of the cLin-28 protein showed overall folding and secondary structures that were very similar to those of the human Lin-28 protein (Figure 11a). The similarities between the cLin-28 protein and the human Lin-28 protein were studied by superimposing their structures in the PyMOL program (http:/ / pymol.sourceforge.net) (Figure 11b). Overall, there were 0.417 RMSD deviation structure pairs.

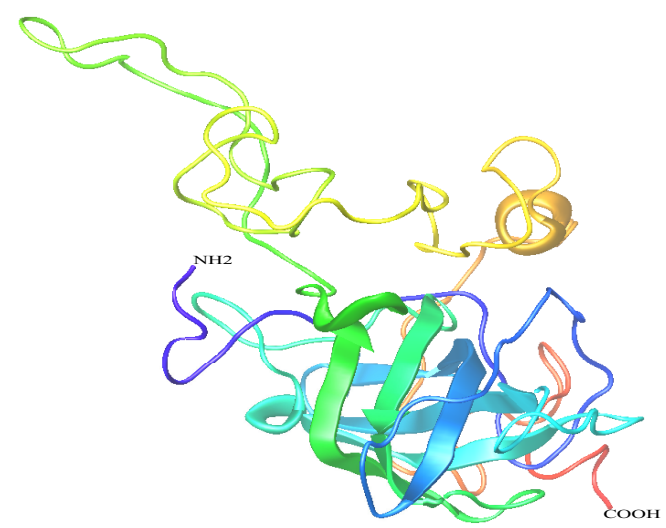

(a)

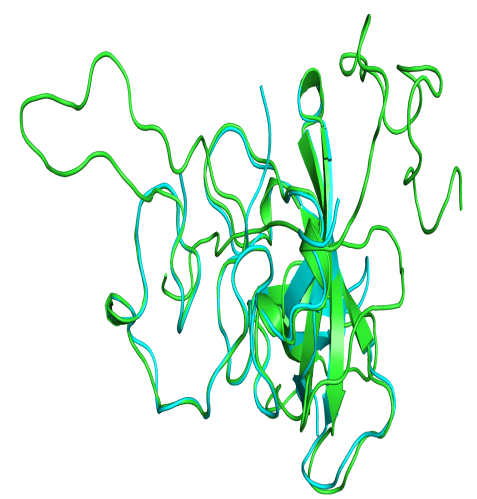

(b)

Figure 11. Modeled 3D structures. (a) The 3D structure of the cLin-28 protein. (b) Stereo ribbon representation of the predicted 3D structure model of the cLin-28 protein (cyan) and the superimposition with the human Lin-28 protein (green). 
The Ellipro server (http:/ / tools.iedb.org/ellipro/) was utilized to predict the epitopic regions using the modeled 3D structure of the cLin-28 protein. The screening revealed that the cLin-28 protein has nine discontinuous with regions with score values of $>0.5$. The highest probability of a discontinuous epitope was calculated to be $80.3 \%$. Table 6 details the amino acids involved in discontinuous epitopes, their sequence locations, the number of amino acids, and the scores. The higher the score is, the greater their potential of being a discontinuous epitope. Their positions of the epitopes on the 3D cLin-28 protein structure are shown in Figure 12.

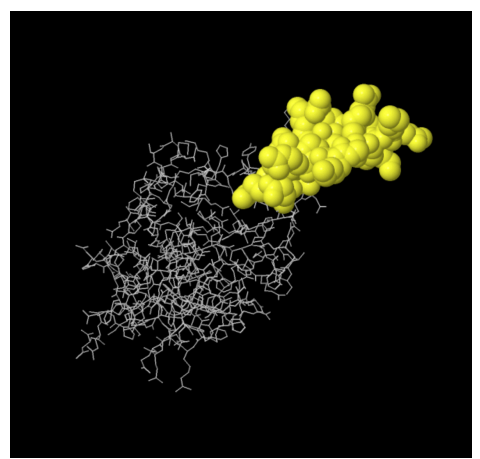

(a)

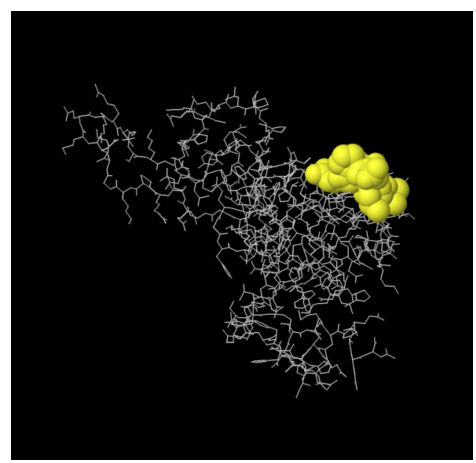

(d)

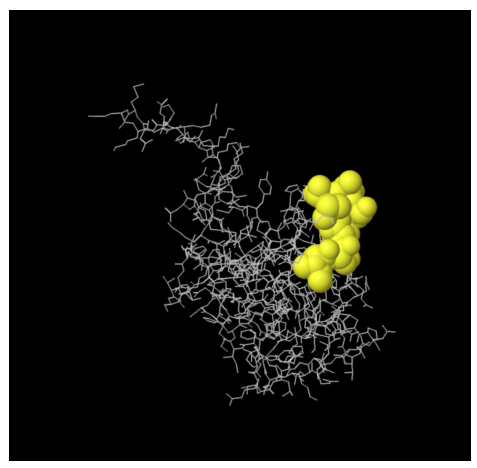

$(\mathrm{g})$

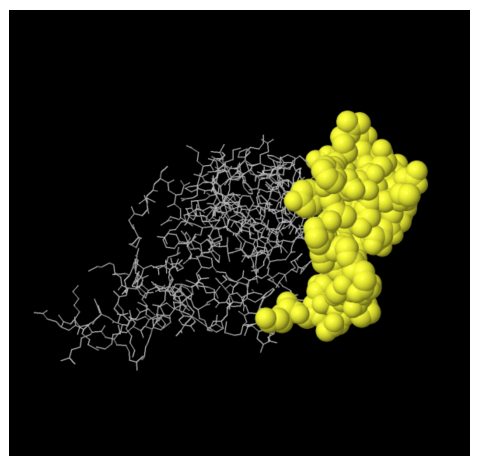

(b)

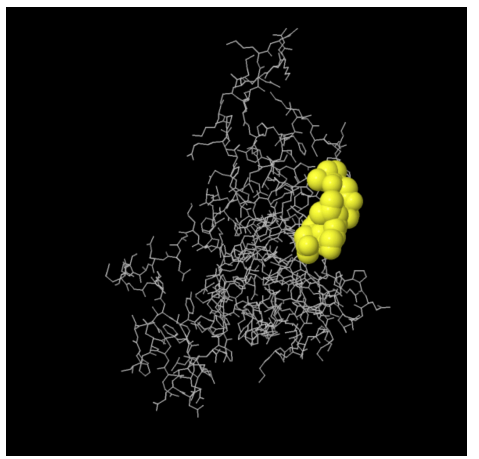

(e)

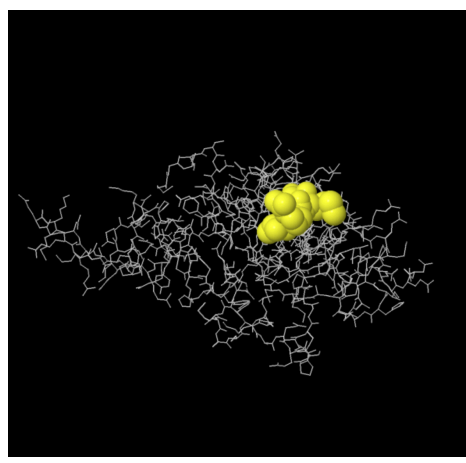

(h)

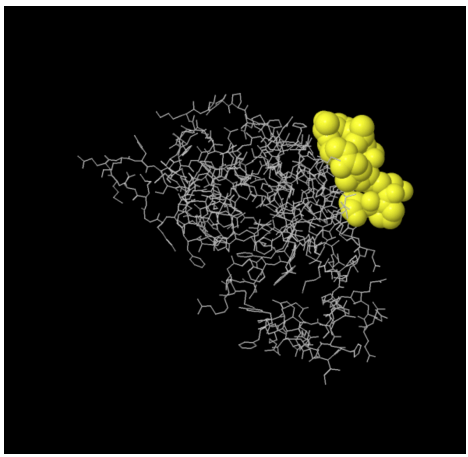

(c)

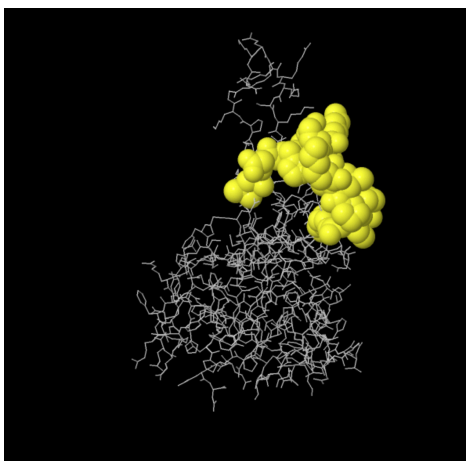

$(\mathbf{f})$

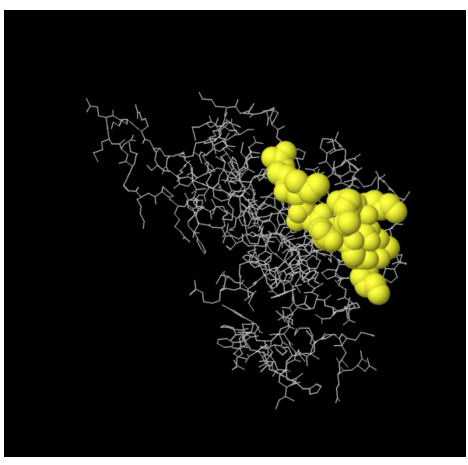

(i)

Figure 12. Three-dimensional representation of discontinuous epitopes (a-i) of cLin-28. The epitopes are shown in yellow, and the bulk of the cLin- 28 protein is shown in grey sticks. 
Table 6. Predicted discontinuous antigenic epitopes of the cLin-28 protein.

\begin{tabular}{cccccc}
\hline Start & End & Peptide & Length & Score & 3D Structure \\
\hline 117 & 134 & ERRPKGKNMQKRRSKGDR & 18 & 0.803 & $\mathrm{~A}$ \\
173 & 205 & KAQQAPSSQGKPAYFREEEEEIHSSAMLPEAQN & 33 & 0.785 & $\mathrm{~B}$ \\
57 & 65 & RAGVALDPP & 9 & 0.709 & $\mathrm{C}$ \\
29 & 35 & EEPQLLH & 7 & 0.702 & $\mathrm{D}$ \\
1 & 6 & MGSVSN & 6 & 0.622 & $\mathrm{E}$ \\
141 & 156 & LDHHAKECKLPPQPKK & 16 & 0.617 & $\mathrm{~F}$ \\
163 & 170 & INHMVASC & 8 & 0.574 & $\mathrm{G}$ \\
45 & 48 & VRMG & 4 & 0.556 & $\mathrm{H}$ \\
94 & 104 & KKSAKGLESIR & 11 & 0.518 & $\mathrm{I}$ \\
\hline
\end{tabular}

\section{Discussion}

Although cDNA sequences are available for the Lin - 28 gene of most species, previously, there were no reports of the full sequence, molecular characterization, and tissue distribution of the Arabian camel Lin -28 gene. This study presents the full-length cLin-28 cDNA sequence from the Arabian camel. The cLin-28 protein has a high degree of homology with other mammalian species and is phylogenetically clustered within the wild bactrian camel and cattle. The cLin-28 mRNA is $715 \mathrm{bp}$ long. It contains an open reading frame of $615 \mathrm{bp}$ that codes for 205 amino acids. The BLAST analysis and multiple sequence alignment of cLin-28 showed that the overall sequence homology of the cLin-28 protein sequence alignment with different species is high and shows similar structural characteristics.

We confirmed that the cLin-28 protein contains two highly conserved domains. The two main domains, an N-terminal cold-shock domain (CSD) and a C-terminal pair of retroviral-type CCHC zinc fingers, were highly conserved in all aligned proteins. The cLin-28 protein binds to a pri- and pre-let-7 microRNA and represses their processing by Drosha and Dicer. Many biochemical and structural observations revealed that the specificity of this interaction is mainly carried by the zinc finger domain with a conserved GGAGA motif. The cLin- 28 protein shares an overall sequence identity of $80 \%$ and contains low-complexity regions at the N-terminus. Any single amino acid mutation in either the CSD or the retroviral-type CCHC zinc fingers eliminates both let-7 binding and processing inhibition. This indicates that both domains are required for Lin-28 function [28].

The species tree was constructed from the cLin- 28 protein and nine of the highly similar mammalian Lin-28 proteins, with each species being represented by its own Lin-28 protein sequence. The internal nodes represent the ancestral sequences from which the present-day sequences have diverged after speciation events that produced two descendant divergent species. The species tree confirmed that the internal node of the Arabian camel protein has a further evolutionary distance from the root than the alpaca protein. The tree also demonstrated that the Wild Bactrian camel and cattle diverged from their common ancestor at a later evolutionary time than the Arabian camel.

We used the ANCHOR web-server to predict disordered regions of the cLin- 28 protein. The 3D-structure of the cLin-28 protein partially lacks an ordered structure, especially at its termini regions. As a result, the cLin-28 protein can be classified as an intrinsically disordered protein. It has been suggested that all transcription factors tend to have fully or partially disordered regions in order to indicate that there is an intrinsic requirement for those transcription factors to be highly flexible and thus to be able to interact with other proteins and DNA [29]. The cLin-28 protein consists of the disordered $\mathrm{N}$-terminal and C-terminal parts and the central largely ordered DNA binding domains.

\section{Materials and Methods}

\subsection{Sample Collection}

Eleven different Arabian camel tissues were obtained from an adult male camel slaughtered at the main slaughter-house in Southern Riyadh. Those tissue types used were spleen, lung, small intestine, heart, liver, kidney, stomach, esophagus, brain, muscle, and testis. All tissue samples were then 
immediately submerged in RNAlater ${ }^{\circledR}$ solution (Qiagen, Hilden, Germany) to avoid RNA degradation and stored at $4{ }^{\circ} \mathrm{C}$ for $24 \mathrm{~h}$ and then at $-20^{\circ} \mathrm{C}$ until use. The other sample tissues were transported on ice to the laboratory to be utilized for proteomic analysis.

\subsection{Isolation of RNA and Synthesis of $c D N A$}

Total RNA was isolated from about $500 \mathrm{mg}$ of each tissue under study using the Trizol Reagent method [30], as described in the manufacturer's instructions (Invitrogen, Carlsbad, CA, USA). The concentration of obtained RNA was measured by the Nanodrop spectrophotometer (NanoDrop; TermoScientifc) at $260 \mathrm{~nm}$, and the integrity and quality of isolated RNA was evaluated using denaturing agarose gel (1\%) electrophoresis. Aliquots of $2 \mu \mathrm{g}$ RNA samples were reverse-transcribed into first strand cDNA with a High-Capacity cDNA Reverse Transcription Kit using the Oligo (dT) primer in compliance with the standard protocol for PCR amplification.

\subsection{Examining Clin-28 Gene Expression by Using PCR and qRT-PCR}

The data from the Arabian camel genome project (http:/ / camel.genomics.org.cn/page/camel/ index.jsp) were used to design PCR and qPCR primers (Table 1$)$. The PCR reaction mixture $(25 \mu \mathrm{L})$ contained $12.5 \mu \mathrm{L}$ of $2 X$ GoTaq $^{\circledR}$ Green Master Mix (Promega, Madison, WI, USA), $1 \mu \mathrm{L}$ of 5 pmol of each primer, $5 \mu \mathrm{L}$ of template cDNA and was carried out by ProFlex PCR System (Applied Biosystems). The PCR amplification conditions were as follows: initial denaturation at $94{ }^{\circ} \mathrm{C}$ for $5 \mathrm{~min}$, followed by 30 cycles at $59{ }^{\circ} \mathrm{C}$ for $5 \mathrm{~s}, 60^{\circ} \mathrm{C}$ for $30 \mathrm{~s}$, and $72{ }^{\circ} \mathrm{C}$ for $45 \mathrm{~s}$. The final extension step was performed at $72{ }^{\circ} \mathrm{C}$ for $10 \mathrm{~min}$. The PCR products were then electrophoresed on $1.2 \%$ agarose gel stained with SYBR ${ }^{\circledR}$ Safe. The obtained PCR fragments were then sequenced according to the Sanger method [31] by using the $3730 \mathrm{X}$ series platform sequencer. In addition, the level of relative expression of cLin- 28 mRNA was measured by examining the 11 different Arabian camel tissues with the fluorescent quantitative real-time PCR (qRT-PCR) method. The GAPDH mRNA was used as an endogenous control. In this experiment, the Fast SYBR ${ }^{\circledR}$ Green Master Mix kit was used, and gene-specific primer pairs were designed to amplify $101 \mathrm{bp}$ of cLin-28. The qRT-PCR reaction mixture included $10 \mu \mathrm{L}$ of Fast SYBR ${ }^{\circledR}$ Green Master Mix (Cat. No., 4385612, Applied Biosystems), $1 \mu \mathrm{L}$ of the forward primer, $1 \mu \mathrm{L}$ of the reverse primer, $3 \mu \mathrm{L}$ of nuclease-free water, and $5 \mu \mathrm{L}$ of cDNA target to give a total volume of $20 \mu \mathrm{L}$. The thermal cycling parameters were as follows: initial denaturation at $95^{\circ} \mathrm{C}$ for $3 \mathrm{~min}$, and amplification of 40 cycles at $95^{\circ} \mathrm{C}$ for $3 \mathrm{~s}$ and then at $60^{\circ} \mathrm{C}$ for $40 \mathrm{~s}$. The threshold cycle $\Delta \Delta$-Ct values for the cLin-28 gene and the GAPDH housekeeping gene were determined in triplicate. Relative quantification of RNA was calculated by the $\Delta \Delta$-Ct method.

\subsection{Protein Digestion and Mass Spectrometry}

The two-dimensional gel electrophoresis (2-DE) coupled with liquid mass spectrometry (LC-MS) was used to identification of cLin-28 protein. This procedure includes the separation of clin- 28 protein based on its isoelctric point (pI) in the first dimension followed by separation on the basis of its molecular weight using sodium dodecyl sulfate polyacrylamide gel electrophoresis (SDS-PAGE). $25 \mu \mathrm{g}$ of Arabian camel protein mixtures were separated by 2-D SDS-PAGE followed by staining of the gel with protein specific dye solution (Coomassie R-240) overnight. After destining, the cLin-28 protein spot ( $\mathrm{pI}$ of 8.50 and Mwt of $22.389 \mathrm{kDa}$ ) was then digested as described before [32]. The tryptic-cleaved peptides mixture was transferred to a clean autosampler vial. Millipore ${ }^{\circledR}$ Ziptips C18 pipette (Tip size:P10, Merck KGaA, Darmstadt, Germany) was performed in order to prepare sample for Matrix-assisted laser desorption/ionization-time of flight (MALDI-TOF) mass spectrometry. $1 \mu \mathrm{L}$ of aliquots were generally sampled directly from the digest supernatant for MS fingerprint analysis by using Axima Performance 1 MALDI TOF/TOF Mass Spectrometer (Shimadzu Corporation, UK). The output data were then searched using the MASCOT search engine (http://www.matrixscience.com). 


\subsection{Structure Modeling}

The secondary structure of cLin-28 protein sequence was generated using Geneious software v10.0.3 [14]. The Phyre2 server (http:/ / www.sbg.bio.ic.ac.uk/phyre2/html/page.cgi?id=index) was utilized to predict the three-dimensional (3D) structure of cLin-28 protein. The structural alignment between modeled clin-28 protein and human Lin-28 protein (PDB:4A4I) was performed by using Pymol software [33]. The quality of the structural alignment was evaluated using PDBe on (https: //swissmodel.expasy.org/interactive).

\section{Conclusions}

In conclusion, 715-bp was sequenced and confirmed by using 3730XL series platform sequencer. The predicted amino acid sequence of cLin-28 mRNA was found to consist of an open reading frame (ORF) of 205 amino acid. The molecular analysis of the 205-amino acid sequence of cLin-28 protein using the Geneious software predicted that this protein has a molecular weight (Mwt) of $22.389 \mathrm{kDa}$ and Isoelectric point (pI) 8.50. Peptide mass fingerprint-mass spectrometry (PMF-MS) analysis of the purified clin-28 protein confirmed the identity of this protein. Expression of cLin-28 protein was examined in several Arabian camel organs, with highest expression occurring in lung, heart, liver, and esophagus. A BLASTp search engine revealed that 205 amino acid translated protein of Arabian camel shared high similarity (98.1-79\%) with Lin-28 from other species. The instability index of cLin-28 protein was also measured to be 58.89 , which classified the protein as unstable. The flexibility analysis revealed that the $\mathrm{N}$-terminal of $\mathrm{CLin}-28$ protein is more flexible than its $\mathrm{C}$-terminal regions. Sequence similarity and phylogenetic analysis showed that the cLin- 28 protein is grouped together with those of Camelus bactrianus and Bos taurus. The predicted 3D structure of cLin-28 protein shows overall folding and secondary structures very similar to those of humans.

Author Contributions: Conceptualization, S.N.A.; Methodology, S.N.A., I.S.A., L.A., F.M.A., D.K.A., S.O.A., K.A.A., and M.A.A.; Software, S.N.A.; Validation, S.N.A., and W.M.A.; Formal Analysis, S.N.A.; Investigation, S.N.A.; Resources, S.N.A.; Data Curation, S.N.A.; Writing-Original Draft Preparation, S.N.A.; Writing-Review \& Editing, S.N.A.; Visualization, S.N.A.; Supervision, S.N.A., M.F.; Project Administration, S.N.A.

Funding: This research was funded by King Abdulaziz City for Science and Technology, Stem Cell Technology localization program, grant number (KACST 20-0115).

Acknowledgments: All authors extend their appreciation to the anonymous referees and editors for their useful suggestions.

Conflicts of Interest: The authors declare no conflict of interest. The founding sponsors had no role in the design of the study; in the collection, analyses, or interpretation of data; in the writing of the manuscript, and in the decision to publish the results.

\section{Abbreviations}

The following abbreviations are used in this manuscript:

ORF Open Reading Frame

RT-PCR Transcription Polymerase Chain Reaction

CSD Cold-Shock Domain

qPCR Quantitative real-time PCR

PMF-MS Peptide Mass Finger Print-Mass Spectrometry

\section{References}

1. Fowler, M. Medicine and Surgery of Camelids; John Wiley \& Sons: Hoboken, NJ, USA, 2011.

2. Manee, M.M.; Alharbi, S.N.; Algarni, A.T.; Alghamdi, W.M.; Altammami, M.A.; Alkhrayef, M.N.; Alnafjan, B.M. Molecular cloning, bioinformatics analysis, and expression of small heat shock protein beta-1 from Camelus dromedarius, Arabian camel. PLoS ONE 2017, 12, e0189905. [CrossRef] [PubMed] 
3. Alawad, A.; Alharbi, S.; Alhazzaa, O.; Alagrafi, F.; Alkhrayef, M.; Alhamdan, Z.; Alenazi, A.; Al-Johi, H.; Alanazi, I.O.; Hammad, M. Phylogenetic and Structural Analysis of the Pluripotency Factor Sex-Determining Region Y box2 Gene of Camelus dromedarius (cSox2). Bioinform. Biol. Insights 2016, 10, BBI-S39047. [CrossRef]

4. Moss, E.G.; Tang, L. Conservation of the heterochronic regulator Lin-28, its developmental expression and microRNA complementary sites. Dev. Biol. 2003, 258, 432-442. [CrossRef]

5. Darr, H.; Benvenisty, N. Genetic analysis of the role of the reprogramming gene LIN-28 in human embryonic stem cells. Stem Cells 2009, 27, 352-362. [CrossRef]

6. Tsialikas, J.; Romer-Seibert, J. LIN28: Roles and regulation in development and beyond. Development 2015, 142, 2397-2404. [CrossRef] [PubMed]

7. Balzer, E.; Moss, E.G. Localization of the developmental timing regulator Lin 28 to mRNP complexes, P-bodies and stress granules. RNA Biol. 2007, 4, 16-25. [CrossRef]

8. Piskounova, E.; Polytarchou, C.; Thornton, J.E.; LaPierre, R.J.; Pothoulakis, C.; Hagan, J.P.; Iliopoulos, D.; Gregory, R.I. Lin28A and Lin28B inhibit let-7 microRNA biogenesis by distinct mechanisms. Cell 2011, 147, 1066-1079. [CrossRef]

9. Newman, M.A.; Thomson, J.M.; Hammond, S.M. Lin-28 interaction with the Let-7 precursor loop mediates regulated microRNA processing. Rna 2008, 14, 1539-1549. [CrossRef] [PubMed]

10. Wang, N.; Yamanaka, K.; Inouye, M. Acquisition of double-stranded DNA-binding ability in a hybrid protein between Escherichia coli CspA and the cold shock domain of human YB-1. Mol. Microbiol. 2000, 38, 526-534. [CrossRef]

11. Pasquinelli, A.E.; Ruvkun, G. Control of developmental timing by microRNAs and their targets. Annu. Rev. Cell Dev. Biol. 2002, 18, 495-513. [CrossRef]

12. Hafner, M.; Max, K.E.; Bandaru, P.; Morozov, P.; Gerstberger, S.; Brown, M.; Molina, H.; Tuschl, T. Identification of mRNAs bound and regulated by human LIN28 proteins and molecular requirements for RNA recognition. Rna 2013, 19, 613-626. [CrossRef]

13. Thummel, C.S. Molecular mechanisms of developmental timing in C. elegans and Drosophila. Dev. Cell 2001, 1, 453-465. [CrossRef]

14. Kearse, M.; Moir, R.; Wilson, A.; Stones-Havas, S.; Cheung, M.; Sturrock, S.; Buxton, S.; Cooper, A.; Markowitz, S.; Duran, C.; et al. Geneious Basic: An integrated and extendable desktop software platform for the organization and analysis of sequence data. Bioinformatics 2012, 28, 1647-1649. [CrossRef]

15. Guruprasad, K.; Reddy, B.B.; Pandit, M.W. Correlation between stability of a protein and its dipeptide composition: a novel approach for predicting in vivo stability of a protein from its primary sequence. Protein Eng. Des. Sel. 1990, 4, 155-161. [CrossRef]

16. Kyte, J.; Doolittle, R.F. A simple method for displaying the hydropathic character of a protein. J. Mol. Biol. 1982, 157, 105-132. [CrossRef]

17. Hopp, T.P.; Woods, K.R. A computer program for predicting protein antigenic determinants. Mol. Immunol. 1983, 20, 483-489. [CrossRef]

18. Karplus, P.; Schulz, G. Prediction of chain flexibility in proteins. Naturwissenschaften 1985, 72, $212-213$. [CrossRef]

19. Kolaskar, A.; Tongaonkar, P.C. A semi-empirical method for prediction of antigenic determinants on protein antigens. FEBS Lett. 1990, 276, 172-174. [CrossRef]

20. Emini, E.A.; Hughes, J.V.; Perlow, D.; Boger, J. Induction of hepatitis A virus-neutralizing antibody by a virus-specific synthetic peptide. J. Virol. 1985, 55, 836-839.

21. Chou, P.; Fasman, G. Prediction of the secondary structure of proteins from their amino acid sequence. Adv. Enzymol. 1978, 47, 45-148.

22. Thompson, J.D.; Higgins, D.G.; Gibson, T.J. CLUSTAL W: Improving the sensitivity of progressive multiple sequence alignment through sequence weighting, position-specific gap penalties and weight matrix choice. Nucleic Acids Res. 1994, 22, 4673-4680. [CrossRef]

23. Altschul, S.F.; Gish, W.; Miller, W.; Myers, E.W.; Lipman, D.J. Basic local alignment search tool. J. Mol. Biol. 1990, 215, 403-410. [CrossRef]

24. Saitou, N.; Nei, M. The neighbor-joining method: a new method for reconstructing phylogenetic trees. Mol. Biol. Evol. 1987, 4, 406-425. 
25. Dosztányi, Z.; Mészáros, B.; Simon, I. ANCHOR: Web server for predicting protein binding regions in disordered proteins. Bioinformatics 2009, 25, 2745-2746. [CrossRef]

26. Jones, D.T. Protein secondary structure prediction based on position-specific scoring matrices. J. Mol. Biol. 1999, 292, 195-202. [CrossRef]

27. Kelley, L.A.; Mezulis, S.; Yates, C.M.; Wass, M.N.; Sternberg, M.J. The Phyre2 web portal for protein modeling, prediction and analysis. Nat. Protoc. 2015, 10, 845. [CrossRef]

28. Piskounova, E.; Viswanathan, S.R.; Janas, M.; LaPierre, R.J.; Daley, G.Q.; Sliz, P.; Gregory, R.I. Determinants of microRNA processing inhibition by the developmentally regulated RNA-binding protein Lin28. J. Biol. Chem. 2008, 283, 21310-21314. [CrossRef]

29. Xue, B.; Oldfield, C.J.; Van, Y.Y.; Dunker, A.K.; Uversky, V.N. Protein intrinsic disorder and induced pluripotent stem cells. Mol. BioSyst. 2012, 8, 134-150. [CrossRef]

30. Hongbao, M.; Young, J.; Shen, C. RNA, DNA and protein isolation using TRI Zol reagent. Nat. Sci. 2008, 6, 66-75.

31. Sanger, F.; Nicklen, S.; Coulson, A.R. DNA sequencing with chain-terminating inhibitors. Proc. Natl. Acad. Sci. USA 1977, 74, 5463-5467. [CrossRef]

32. Shevchenko, A.; Tomas, H.; Havli, J.; Olsen, J.V.; Mann, M. In-gel digestion for mass spectrometric characterization of proteins and proteomes. Nat. Protoc. 2006, 1, 2856. [CrossRef]

33. DeLano, W.L. Pymol: An open-source molecular graphics tool. CCP4 Newsl. Protein Crystallogr. 2002, $40,82-92$.

(C) 2019 by the authors. Licensee MDPI, Basel, Switzerland. This article is an open access article distributed under the terms and conditions of the Creative Commons Attribution (CC BY) license (http://creativecommons.org/licenses/by/4.0/). 